\title{
THE EPISTLE TO THE GALATIANS AND CLASSICAL RHETORIC: PART 3
}

\author{
Janet Fairweather
}

\section{Summary}

It has been demonstrated in Parts 1 and 2 of this study (Tyndale Bulletin, May 1994) that rhetorical criticism was applied to Paul's Epistles in late Antiquity and that Paul himself certainly displays a knowledge of some sophisticated terms and concepts derived from the Greek theory of rhetoric, though it may still be doubted whether he obtained this knowledge direct from pagan schools or textbooks. What justification did he have, then, for representing his discourse as alien to the ropi $\alpha$ of this world? It will emerge, first through a close reading of Galatians and then through more general consideration of Paul's handling of the 'five parts of rhetoric' that, although at the more superficial levels Paul makes use' of many of the techniques favoured by classical orators, the conceptual framework in which he operated was different from that of pagan sophists and the bases of his argumentation were distinct and innovative.

\section{The Word of the Cross and the Wisdom of this World: Galatians re-examined}

\section{Proem-narration-arguments-epilogue}

As is well known, the greeting which opens the Epistle to the Galatians combines Jewish elements with Greek in an innovative synthesis. The rebuke-opening $\theta \alpha v \mu \alpha \dot{\zeta} \omega \omega$ ö $\tau$ has been shown to relate to Hellenistic epistolary convention, ${ }^{1}$ but there are elements in the proem to Galatians which, at first sight at least, seem deliberately anti-rhetorical. Chrysostom ${ }^{2}$ was right to point out the oddity of placing a final Amen in a preface, though actually it is not without parallel in the Pauline

1See Hansen, Abraham in Galatians, 28.

2Migne 619, lines 58ff., Alexander p. 6 col. 1. 
epistles. ${ }^{3}$ There is nothing remotely conciliatory about the proem to Galatians: its vehemence is, indeed, startling, and to curse the opposition is an audacious opening ploy by any standards. This is the only extant Pauline epistle-opening which does not contain a thanksgiving. Here, then, is no conventional captatio benevolentiae. However, according to Aristotle, a deliberative speech might on occasion appropriately begin with exciting of prejudice and magnification of the importance of the subject at issue. ${ }^{4}$ Arguably, Paul's prooemium falls within those guidelines. His denial of man-pleasing intent is an overt rejection of the kind of oratorical ideal set out by Cicero in Orator 21.69: erit igitur eloquens. . . is qui in foro causisque civilibus ita dicet, ut probet, ut delectet, ut flectet ('The eloquent man will be one who speaks in the forum and in civil disputes in such a way that he convinces, pleases and sways opinion'). However, denial of the intention to please is paralleled in, for example, a speech credited to one C. Claudius in the Roman Antiquities of Dionysius of Halicarnassus (11.9.1):

I ask this, Appius, of you men who are at the head of the commonwealth and are in duty bound to consult the common interest of all rather than your private advantage, that if I speak some truths with frankness instead of trying to please you, you will not be offended on that account, when you consider that I shall not make my remarks with any intent to abuse and insult your magistracy, but in order to show in how great a sea the affairs of the commonwealth are tossed and to point out what will be both their safety and their reformation.

Thus Paul's proem is not so remote from thought-forms acceptable to classical orators as might at first appear.

Again, if we consider the autobiographical narrative in Galatians 1:11ff., we find it not blatantly full of self-justification, and thus it departs from the norm of apologetic narrative. Paul's heavy emphasis on his murky past as a persecutor of the Church is, as Chrysostom found, remarkable, and certainly it seems the earliest example of what was to be a most important

${ }^{3}$ See Rom. 1:25.

${ }^{4}$ Aristotle, Rhetoric 3.14.12 (1415b 33ff.). 
element in later Christian confessional discourse: public declaration that 'I once was lost, but now am found.' However, even Paul's bold confession of his past guilt had pagan rhetorical analogues. From Quintilian's discussion (9.2.16ff.) of the rhetorical figure praesumptio, $\pi \rho{ }^{\prime} \lambda \eta \mu \psi \iota \varsigma$-anticipation of one's opponent's arguments, we hear of a sub-species of this figure actually called confessio, whereby an advocate for the defence might concede that his client was guilty of one of the charges brought against him (loc. cit. 18). We may deduce from a remark by Seneca the Elder (Controversiae 7 pr. 3) that this was not reckoned a device to be used if there were any alternative. But arguably, Paul had no alternative: the facts about his past were too well known. His impassioned declaration in Galatians 1:20 that he is not lying, certainly had plentiful rhetorical precedent in Greek-speaking antiquity. For example, Demosthenes, addressing the Athenian assembly in his speech On the False Embassy, makes the following statement of principle: 'There is no way in which a man could do you greater wrong than by telling lies.' 5 Then, as now, such declarations could be sincere, but were tainted by frequent dishonest misuse of them. Paul's account of the years immediately following his conversion does not tally exactly with the parallel narrative in Acts, and the modern commentator, like a jury, has at least to call his truthfulness into question. Thus it is hard to pinpoint anything distinctively 'Jewish', 'Christian' or 'not of this world' in Paul's mode of $\delta$ in $\gamma$ ris in Galatians. However, the arguments addressed to Cephas in the speech recorded at its conclusion strike one as far removed from the hard-edged rationality characteristic of contemporary pagan orators. It is interesting to note, too, that $\sigma v \gamma \kappa \alpha \tau \alpha \dot{\alpha} \beta \alpha \sigma \varsigma$, , 'descending to the level of others', a quality repeatedly detected by Chrysostom ${ }^{6}$ in the writings of Paul,

\footnotetext{
${ }^{5}$ Demosthenes, Oratio 19 (De Falsa Legatione) 184.

${ }^{6} \mathrm{~A}$ Thesaurus Linguae Graecae word-search reveals it to have been a favourite word of his, but not very common in pagan authors. Colson's hypothesis that $\sigma v \gamma \kappa \alpha \tau \alpha \dot{\beta} \alpha \sigma \iota \varsigma$ may somewhere have been classified as a rhetorical figure seems untenable on the evidence available to me, though see Bullinger, Figures of Speech used in the Bible, $871 \mathrm{ff}$.
} 
seems to have been regarded by Philodemus as something which the art of rhetoric signally failed to promote. ${ }^{7}$

The argumentative part of Galatians can certainly be analysed in terms derived from classical rhetoric, as Chrysostom's commentary shows, but we need to ask whether these are the best terms in which to conduct an appreciation of Paul's thought-processes in the central chapters of the Epistle.

These thought-processes have been described by one critic as a 'sequence of preposterous sophistries', 8 and it is certainly not a foolish question to ask how much Paul's argumentative procedures owe, directly or indirectly, to the Greek sophistic movement. We need to ask why Paul did not react to the Galatians' problem in what would seem to us the obvious way: by setting out texts from Old Testament prophecy as illustrations of the Messiah's twofold destiny 'to be a light to lighten the Gentiles and to be the glory of thy people Israel' (Lk. 2:32). Why, instead, are we faced with audacious philological

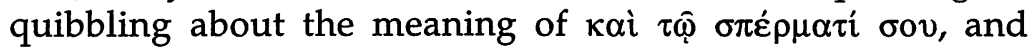
recondite allegorising typology? Galatians was an early Epistle: evidently Paul had yet to shake off all the effects of his preChristian schooling, including Hellenistic traditions of $\gamma \rho \alpha \mu \mu \alpha \tau \kappa \eta$ which were not confined to the Jewish world alone.

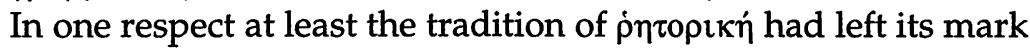
too. The fact that he argues one side of the case so forcibly, without even feeling it necessary, out of politeness, to concede that his opponents have at least the weight of tradition on their side, suggests heavy indebtedness to a tradition of adversarial debating, maybe even one in which people learnt to make 'the weaker argument seem the stronger', 9 like the sophists of fifthcentury Greece. It is probably unnecessary, however, to look outside Paul's Pharisaic upbringing in search of this tradition. Despite the fact that Philo had written a treatise on the theme,

\footnotetext{
7Philodemus, Rhetorica 2.25 (Col. XXXI, line 15) (ed. S. Sudhaus; Leipzig: 1892-6; repr. Amsterdam: Hakkert, 1964).

$8 \mathrm{M}$. Goulder in R. Alter and F. Kermode (eds.), The Literary Guide to the Bible (Collins: London, 1987) 489.

${ }^{9}$ Protagoras cited in Aristotle, Rhetoric 2.24.11 (1402 a 23ff.). See W.K.C. Guthrie, A History of Greek Philosophy, Vol. 3 (Cambridge: CUP, 1969) $178 \mathrm{ff}$. on the rhetorical teaching of the early sophists.
} 
'That the worse is wont to attack the better', which includes severe strictures on the hypocrisy of Hellenistic philosophical preachers, 10 nevertheless the notion that it is good intellectual exercise to contrive arguments in favour of a difficult proposition was something which the Jews took to with great alacrity. An early rabbinic saying declared that 'no one is to be appointed a member of the Sanhedrin unless he is able to prove from Biblical texts the ritual cleanliness of a reptile.'11 In 4 Maccabees 8:16ff., just before an account of a Jewish groupmartyrdom, we are invited to imagine what arguments might have been used-but in fact were not-in favour of avoiding torture and death by agreeing to eat pork at the behest of King Antiochus. Practice in arguing for both sides on issues raised by the Torah may well have contributed to the 'pricks' against which Saul is said to have been 'kicking' at the time of his conversion. In Galatians we find him adopting an unorthodox position, with regard to circumcision, which would have seemed to his opponents as hard to accept as the cleanliness of reptiles, and the breaking of the prohibition on pork, which the infant church, following Peter's dream reported in Acts 10:9ff., had also come to countenance.

After the impassioned rebuke which opens chapter 3, there is a sense in which Paul, having established his right to speak with authority, leaves the law-court behind and enters the schoolroom. However, as the Jewish schoolroom was primarily a forum for the discussion of the Law, the step from one to the other is not a long one. The 'schoolroom' in the back of Paul's mind was the Pharisaic beth midrash, the realm of the


had come to deplore (1 Cor. 1:20), but which inevitably had left a deep impression on his ways of thinking. ${ }^{12}$ Its characteristic

${ }^{10}$ Quod deterius potiori insidiari solet, esp. $71 \mathrm{ff}$.

${ }^{11}$ Two versions of this dictum are cited in S. Lieberman, 'Rabbinic interpretation of Scripture' (1962) in H.A. Fischel, Essays in Greco-Roman and related Talmudic Literature (Ktav: New York, 1977) 289-324

12I follow here Hengel's identification (The Pre-Christian Paul, 42.) of Paul's betes noires with figures from the Pharisaic establishment. 
activity was that favourite pursuit of Hellenistic intellectuals, 13 the $\zeta$ ' $\tau \eta \mu \alpha$ ('seeking, research, enquiry', from $\zeta \eta \tau \varepsilon$ ' $\omega$ 'seek'), the Jewish version of which was known as midrash (from darash, likewise a verb meaning 'seek'). ${ }^{14}$

The main question at issue in Galatians-whether Gentile Christians need to be circumcised-is described as a $\zeta \dot{\eta} \tau \eta \mu \alpha$ in Acts 15:2, where we are told that Jewish Christians


$\delta v \dot{v} \alpha \sigma \theta \varepsilon \sigma \omega \theta \bar{\eta} v \alpha \mathrm{l}$, with the consequence that Paul, Barnabas and others were sent to consult with the apostles and elders in

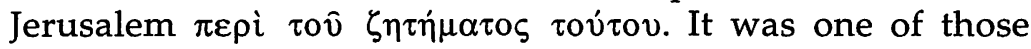
peculiarly Jewish $\zeta \eta \tau \eta \dot{\mu} \mu \tau \alpha$ which Gallio, Proconsul of Achaia, would certainly have regarded as none of his business, having nothing to do with breach of (Roman) law or serious felony (Acts 18:12-17). It has been found that Paul's formulae for introducing biblical citations have parallels in rabbinic midrash. ${ }^{15} \mathrm{~A}$ rich repository of thinking to some extent analogous to Paul's in Galatians is the commentating by Philo on the Genesis Abraham-narrative, contained in the treatises known as De migratione Abrahami, Quis rerum divinarum heres? and De congressu quaerendae eruditionis gratia. ${ }^{16}$

It does not, of course, follow from Paul's self-evident debt to Judaism that it is inappropriate to analyse his arguments in terms of classical rhetoric. The source or inspiration for the influential set of precepts on Torahinterpretation ascribed to Hillel lay most likely in the area of Greek rhetorical theory where dialectic and jurisprudence overlapped, to which theorists by Paul's day had given the

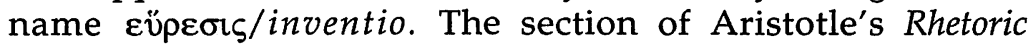
concerned with topics of enthymemes (2.22.13ff.; 1396b 20ff.)

\footnotetext{
${ }^{13}$ See R. Pfeiffer, A History of Classical Scholarship from the beginnings to the end of the Hellenistic Age (Oxford: Clarendon, 1968) 69ff., principally on

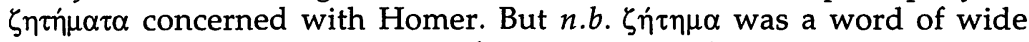
implications, used as a synonym for $\pi \rho$ ó $\beta \lambda \eta \mu \alpha$, and could cover questions of all types and descriptions, including questions of natural science.

${ }^{14} \mathrm{Kittel}, \mathrm{TDNT}$, strangely has no detailed treatment of $\zeta \dot{\eta} \tau \mu \alpha$.

15 See G.W. Hansen, Abraham in Galatians (JSNTS 29; Sheffield: JSOT Press, 1989), Appendix 3, $201 \mathrm{ff}$.

${ }_{16}$ All in volume 4 of the Loeb Philo, ed. and trans. F.H. Colson, G.H. Whittaker (Cambridge, Mass. and London, 1932).
} 
and the opening chapters of the Rhetorica ad Alexandrum ${ }^{17}$ give some idea of the kind of context where such ideas might have developed. Philo, whose cultural proximity to Gamaliel's milieu has been noted, explicitly acknowledges his large debt to Hellenism, and his allegorical method had plentiful precedent in the work of commentators on Homer. 18 Again, Paul's eloquence can hardly be said to abate upon his entry into the Jewish 'schoolroom' . His discourse in the central chapters does not entirely lack apologetic overtones and eulogistic touches, as Chrysostom notes with reference to Galatians 4:12-14,19 and undoubtedly can be analysed as belonging to the genus deliberativum, for Paul is, after all, engaged in the offering of advice to some assemblies: $\tau \alpha \hat{\imath} \varsigma \dot{\varepsilon} \kappa \kappa \lambda \eta \sigma i \alpha \iota \varsigma \tau \hat{\eta} \varsigma \Gamma \alpha \lambda \alpha \tau i \alpha \varsigma$. It is

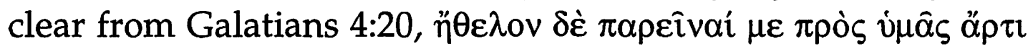

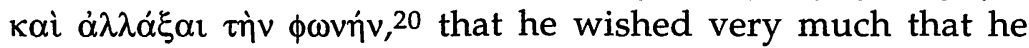
could have been addressing the Galatians orally, and thus that

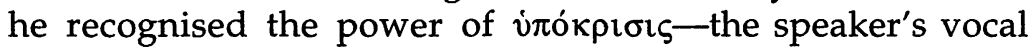
delivery and physical presence. Paul's arguments are diversified by $\pi \alpha \rho \alpha \delta \varepsilon i \gamma \mu \alpha \tau \alpha$, allegory and sententious utterances, all of which are reckoned as effective modes of persuasion by the classical theorists.

A note of caution is required here, however. Chrysostom once remarks, refreshingly, that 'God in the Old Testament' provided precedent for Paul's use of 'human' $\pi \alpha \rho \alpha \delta \varepsilon i \gamma \mu \alpha \tau \alpha .21$ The same could be said of Paul's allegorical method and his sententiousness. The allegories of Philo and

17Especially 1422a.

18Pfeiffer, History of Classical Scholarship, Index, 291 s.v. 'allegorical interpretation'; N.J. Richardson, 'Homeric professors in the age of the sophists', Proceedings of the Cambridge Philological Society N.S. 29 (1975) 6581 .

${ }^{19}$ See Migne Patrologia Graeca, Vol. 61, 658.58ff.; 659.6; 34ff.; trans. G. Alexander, The Nicene and Post-Nicene Fathers, 1st series, Vol. 13, p. 31, col. 2 ; p. 32, col. 1 .

20I take this last phrase to mean 'change my tone of voice'; the alternative interpretation suggested by Betz, 'exchange my voice' (sc. for the letter), seems forced.

21Migne 653, lines 36ff.; Alexander, 27, col. 2. Both Greek and Hebrew had terms for discourse in which divine matters are described in human terms: see Bullinger, Figures of Speech, 871. 
Paul about the family of Abraham may be compared with the 'word of the Lord' in Ezekiel 23 about two sisters, Oholah and Oholibah, who are declared to stand for Samaria and Jerusalem respectively. As for sententious utterances, it will be remembered that a whole book of the Bible is devoted to proverbs. We should beware of the European-centred view of things evident when Betz, with reference to the use of similitudo/ $\pi \alpha \rho \alpha \beta 0 \lambda \eta$ in Galatians 3:5, gives us references to Quintilian's Institutio Oratoria, Lausberg's Handbuch and Martin's Rhetorik, but makes no mention of the parables of Jesus. The most pertinent parallels to Paul's phrasing in Galatians 3:15 are, in fact, the sweeping 'No-one. .' statements in Mark 2:21f. Regarding the general texture of New Testament discourse, it comes as a considerable surprise, from the viewpoint of a classicist, to learn that in Hebrew and Aramaic texts the same word, mashal, was used to mean both 'proverb' and 'parable' /'allegory', hence the strange use of $\dot{\varepsilon} v \pi \alpha \rho o u$ ials to mean 'in veiled language' at John 16:25.22 This identification of concepts was foreign to Graeco-Roman literary theory ${ }^{23}$ and needs to be borne in mind by any critic of New Testament discourse, not excluding the Epistles of St. Paul. However, we have established that an intellect capable of manipulating such a sophisticated Greek concept as $\mu \varepsilon \tau \alpha \sigma \chi \eta \mu \alpha \tau i \zeta \varepsilon \iota v$ was far from being limited to Hebraic categories of thought.

As for specific pagan-Greek models for the general layout of Paul's argumentation, I have yet to find clear evidence for these either in Greek rhetorical theory about deliberative oratory and $\theta \dot{\varepsilon} \sigma \mathrm{\varsigma}$-composition, or in actual philosophical letters and short treatises belonging to the period up to Paul's lifetime.

22See Kittel TDNT s.v. $\pi \alpha \rho \circ \mu$ i $\alpha$; for usages in post-O.T. Hebrew and Aramaic texts see M. Jastrow, A Dictionary of the Targumim, Talmud Babli, Yerushalmi and Midrashic Literature (New York, 1950), Vol. 2, 855, where the following range of possible translations is given, 'a truth substantiated by an illustration, wise saying, fable, allegory, example, mashal'.

23Prof. Russell, per litt., refers me to Epistulae Socraticorum 36.1 (in Epistolographi Graeci, ed. R. Hercher [Paris: Didot, 1873; repr. Amsterdam: Hakkert, 1965]) for an association between $\pi \alpha \rho o u \mu i \alpha \mathrm{l}$ and $\pi \alpha \rho \alpha \beta 0 \lambda \alpha i$, but a Thesaurus Linguae Graecae search suggests that such an association was non-standard outside Christian texts. 
There are specious parallels to be drawn, certainly, but I do not think they amount to much.

Indeed, a particularly good measure of the distance between Paul's thinking and that of a conventional, pagan, Hellenistic orator may be gained from reading the precepts on deliberative oratory in the Rhetorica ad Alexandrum, a treatise ascribed to Aristotle, ${ }^{24}$ difficult to accept as being by the same author as the Rhetoric proper, but generally believed to belong to his time:

...one delivering an exhortation must prove that the courses

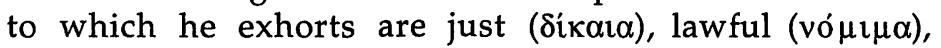

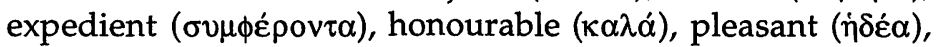
and easily practicable ( $\dot{\rho} \alpha \dot{\delta} \delta 1 \alpha \pi \rho \alpha \chi \theta \hat{\eta} v \alpha \mathrm{l})$; failing this, in case the courses he is urging are disagreeable, he must show that they are feasible ( $\delta v v \alpha \tau \alpha$ ) and also that their adoption is unavoidable ( $\dot{\alpha} \vee \alpha \gamma \kappa \alpha \hat{i} \alpha)$. One dissuading must apply hindrance by the opposite means: he must show that the action proposed is not just, not lawful, not expedient, not honourable, not pleasant and not practicable; or failing this, that it is laborious ( $\dot{\varepsilon} \rho \gamma \hat{\omega} \delta \varepsilon \varsigma$ ) and not necessary (ovik

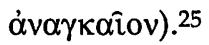

The criteria recommended here, like the very similar ones set out by the later progymnasmatic theorists 26 in their prescriptions for rhetorical $\theta \varepsilon$ ćç-writing, are conspicuous by their absence from the arguments in Galatians. Paul does not present us with an urbane discussion of whether circumcision is just, lawful, expedient, honourable or the reverse. Even when

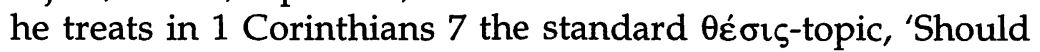
one marry?', 27 his approach is quite different. True, he pronounces certain things $\kappa \alpha \lambda \alpha$ in this passage, and elsewhere in his writings we find some of the other standard terms of commendation and disapproval used from time to time: what is

24Loeb edition: Aristotle, Problems XXII - XXXVIII, Rhetorica ad Alexandrum ed. and trans. W.S. Hett and H. Rackham (London and Cambridge, Mass., 1937).

${ }^{25}$ Rhetorica ad Alexandrum, 1421b 23ff.

${ }^{26}$ Hermogenes, Apthonius and Theon, Progymnasmata, in Rhetores Graeci ed. L. Spengel (Leipzig, 1854; repr. Minerva: Frankfurt, 1966) Vol. 2, 1-130. 27See Quintilian 3.5.5-11. 
distinctive about his approach is that he presents himself as delivering authoritative judgements either as commanded by the Lord (1 Cor. 7:10) or on the strength of his being, through the Lord's mercy, trustworthy (7:25). Claims to possess authority were not in themselves alien to the Graeco-Roman rhetorical tradition and their value in deliberative oratory was recognised. As Quintilian puts it (3.8.13): valet autem in consiliis auctoritas plurimum. ${ }^{28}$ Nevertheless Paul's appeals to a divinely sanctioned apostolic authority, here and elsewhere, seem part of an effort to set himself apart from the assembly-orator of the Greek pagan city, who reckoned to sway his hearers chiefly by standard arguments based on human rationality. His attitude may be compared with that expressed by Philo in Quod deterius potiori insidiari solet 72 :

Sophists. . .make our ears ache with their demonstrations of the social character of righteousness ( $\tau \dot{\eta} v \delta \imath \kappa \alpha \iota \sigma v i v \eta v$



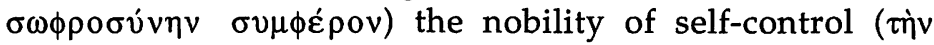

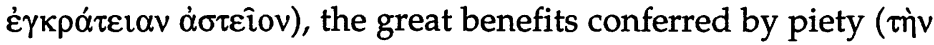
$\varepsilon \dot{v} \sigma \varepsilon \dot{\beta} \varepsilon \imath \alpha \nu \dot{\omega} \phi \varepsilon \lambda \iota \mu \dot{\omega} \tau \alpha \tau o v)$, the power of every kind of virtue to bring health and safety. On the other hand they dwell at great length on the unsociability of injustice, on the loss of health entailed by a licentious life, and prove ad nauseam that


that serious harm is occasioned by all other forms of wickedness. And nevertheless they entertain all the time sentiments quite at variance with the things which they say.

To return to the debate on circumcision in Galatians: the Auctor ad Alexandrum includes within the scope of deliberative rhetoric, along with 'legislation...the form of the constitution...alliances and treaties with other states... war. . peace. . .finance', issues concerning 'religious ritual' ${ }^{29}$ His detailed instructions on how to speak about rites of religion, specifically about proposals 'to maintain the established ritual as it is. . to alter it to a more splendid form, or alter it to a more modest form', take us into an intellectual

${ }^{28} \mathrm{Cf}$. Aristotle, Rhetoric 2.1.3; 1377b 25ff.

29 Ibid., 1423a 30ff. 
milieu very far removed from that of Paul, who might, however, have smiled if he had heard a pagan orator faced with an economic crisis arguing 'that probably it is not the cost of the sacrifices but the piety of those who offer them that gives pleasure to the gods. ${ }^{30}$ Again, it is only in some general, common-sense, respects that Paul's treatment of arguments in Galatians conform to the guidelines for $\theta \dot{\varepsilon} \sigma \iota \varsigma$-writing in the progymnasmatic treatises. ${ }^{31}$ These seemed worth examining in this context because Galatians is open to analysis as a single$\theta \dot{\varepsilon} \sigma \iota \varsigma$ deliberation, and there is reason to believe that the progymnasmata had been in use since the time of the Auctor ad Alexandrum. ${ }^{32}$ Certainly Paul begins his arguments in Galatians

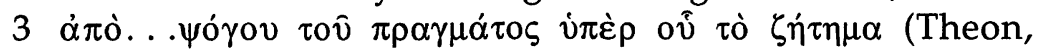
Progymnasmata 121.2f.), and he amplifies his arguments later with a well-chosen historical $\pi \alpha \rho \alpha \delta \varepsilon i \gamma \mu \alpha$ (ibid. 122.28), but he makes no appreciable use of the recommended argumentative topics. The fact is that Paul, like Philo, whose fragmentary treatise De aeternitate mundi has been convincingly analysed as an exposition of a $\theta \dot{\varepsilon} \sigma \imath \varsigma, 33$ was an advanced thinker, and, outside elementary schools, a great deal of flexibility was customary in the treatment of such themes, which were regarded as more the province of philosophers than orators. ${ }^{34} 4$ Maccabees will serve as another striking example of the

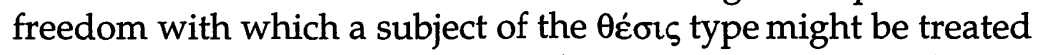
by an accomplished writer. Maybe the young Saul had once learnt rules for the treatment of $\theta \varepsilon \dot{\varepsilon \varepsilon \iota s, ~ b u t, ~ i f ~ s o, ~ h e ~ h a d ~ l o n g ~}$ outgrown them; in any case the progymnasmata would surely have required heavy modification for use by observant Jews: the versions known to us are intimately bound up with pagan mythology as well as with a pagan philosophical outlook.

To consider now a specific case where Paul's argument in Galatians has been suspected of being influenced by a classical literary form: Betz postulates a model in Hellenistic

30Ibid., 1423b $27 \mathrm{ff}$.

31See n. 26 above.

32Ibid., 1436a 25.

${ }^{33}$ See D.T. Runia, 'Philo's De aeternitate mundi: the problem of its interpretation', Vigiliae Christianae 34 (1980) 105-151.

${ }^{34}$ See Fairweather, Seneca the Elder, $104 \mathrm{ff}$. 
philosophical letter-writing for what he sees as a shift from apologetic argumentation to paraenesis at Galatians 5:1.35 Here a warning needs to be given against the supposition that there is extant a large corpus of unquestionably pre-Pauline Greek philosophical letters. Would that this were the case. Uppermost in Betz's mind appears to have been Paul's near-contemporary, Seneca the philosopher, who quite frequently changes the direction of argument of his Epistles, with contrived informality, about two-thirds of the way through, leaving behind whatever topic of Stoic doctrine has been under consideration, and turning to exhortation on a quite different theme, incorporating, typically, some dictum by a non-Stoic thinker. ${ }^{36}$ Now, first of all, my guess would be that this epistolary procedure of Seneca's was completely idiosyncratic. It is certainly hazardous to assume that it had widespread Greek precedent. Evidence is in short supply, very few complete philosophical treatises having survived from the period between Aristotle and Seneca. Epicurus' third Epistle (to Menoecius), is analysed as follows in Cyril Bailey's edition: Introduction; First Principles; the Moral Theory; Peroration, ${ }^{37}$ and a rather similar format, in which exposition of physics is followed by consideration of the ethical consequences of the physical doctrine, is to be found in a little treatise, known to Philo, called On the nature of the Universe, and falsely ascribed to an early follower of Pythagoras called Ocellus of Lucania. ${ }^{38}$ But I have so far in my explorations of pre-Pauline literature discovered nothing closer to a 'doctrinal exposition + moral exhortation' format, and I cannot pretend that examination of the layout of such treatises, any more than the Senecan

${ }^{35}$ Galatians, $253 \mathrm{ff}$.

${ }^{36}$ Betz is unspecific about which Greek texts he has in mind; Hildegard Cançik's analysis of Seneca Ep. 76, which he cites in Galatians, 254, n. 15, provides no documentation from ancient texts outside the Senecan corpus. ${ }^{37}$ Epicurus, ed. C. Bailey (Oxford: Clarendon, 1926) 327ff.

38'Ocellus Lucanus', ed. R. Harder (Berlin: Weidmann, 1926); see Philo, De aeternitate mundi 12. 
exemplars, offers much assistance to the would-be rhetorical analyst of Galatians. ${ }^{39}$

It seems to me that the argumentative section of Galatians is much more of an integrated unity than either Betz's or Chrysostom's analysis suggests, and ties in well with what precedes and follows it. The whole argument is paraenetic, despite the passionate self-involvement which occasionally makes for an apologetic slant. The theme announced at 3:3: 'Having begun with the Spirit, are you now ending with the flesh?', is picked up at 5:16: 'But I say walk by the Spirit and do not gratify the desires of the flesh', and even later in the Epistle, at 6:8 and 6:12-15. Paul's arguments from Galatians 2 (narration) to 6 fin. (epilogue) might be summarised simply as follows:

\footnotetext{
'No' to Gentile circumcision: 'Yes' to the Spirit.

'No' to the Law: 'Yes' to faith.

'No' to slavery: 'Yes' to sonship.

'Yes' to freedom: 'No' to the flesh.
}

The treatment of these themes is worked out with some elaboration, but it is all of a piece. As if to make absolutely sure that he has tied up all the loose ends in his argument, at 6:12f. Paul equates the campaign of the circumcision-party with a desire to 'glory in your flesh' ${ }^{40}$ Comparison with classical texts where 'ring-composition' has been detected might prove enlightening. I think particularly of Solon's verse-sermon $\pi \varepsilon \rho i$

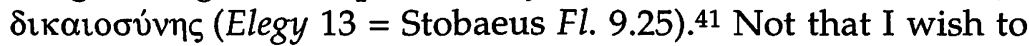
presume that Paul had read Solon, even though this particular elegy might conceivably have found its way into a Jewish anthology. 'Ring composition' may be regarded as a natural enough improvisatory pattern. It does not seem to have been a format standardly recommended by rhetorical theorists,

${ }^{39}$ Burton L. Mack, Rhetoric and the New Testament (Fortress: Minneapolis, 1990) detects a format of this type in the Sermon on the Mount in Matthew, but the analysis is not compelling.

40For useful background to Paul's thinking about circumcision and the flesh see Philo, Quaestiones in Genesin 44.

${ }^{41}$ See e.g. ed. and trans. J.M. Edmonds, Elegy and Iambus, Vol. 1, $126 \mathrm{ff}$. (Cambridge, Mass./London: Heinemann, 1931). 
though some jocular comments on it by an Augustan rhetorician are recorded by Seneca the Elder. 42

To label, as Betz does, 5:1-6:10 as a 'paraenetic section' distinct from the preceding argumentation proper, does not do complete justice to the broad sweep of Paul's thought in the Epistle, and nor does Chrysostom's marking of the start of a distinct moral excursus at 5:13. However, both critics were influenced in their analyses by memories of Paul's epistolary practice elsewhere, and I will not say they were entirely unjustified in detecting a characteristically Pauline shift of argumentative emphasis after the allegory of 4:21ff. (Betz's 6th argument), though I would prefer to mark the shift where Chrysostom does, at 5:13, rather than right at the beginning of the chapter, as 5:1-12 seem to me to relate very closely to the preceding allegory. The closest analogue for both the form and the content of Galatians is to be found in the Epistle to the Romans. There, a decisive end to doctrinal exposition is made at 11:36, and a new beginning is made with the exhortation, regarding matters of the flesh, at 12:1: 'I appeal to you therefore, brethren, by the mercies of God, to present your bodies as a living sacrifice, holy and acceptable to God, which is your spiritual worship.' Though the parallel is not exact, it is apposite to consider Paul's mode of transition here in relation to that between Galatians 5:12 and 13 .

Ever since Paul's time, the format, 'doctrinal exposition followed by moral exhortation', has been commonplace in Christian preaching. The Migne editor of Chrysostom in Patrologia Graeca LXI, col. 609 comments that this author's normal practice (to which the Commentary on Galatians is an exception) was to couch his commentating in the form of homilies ending in moral exhortation (ita ut concio quaelibet ethica adhortatione claudatur). Paul himself was obviously a primary model for this homiletic form. Did he originate it? This is not particularly easy to believe. It would not surprise me at all if evidence that I have overlooked emerges for its prior use either in synagogue preaching or in Greek philosophical letters. This much may be said with reasonable confidence: it does not

${ }^{42}$ Cestius Pius cited in Seneca, Controversiae 7.7.19. 
seem to have been standardly promoted by rhetorical theorists on the genus deliberativum.

The place of the allegory (Gal. 4 fin) within the argumentation is seen in a slightly altered perspective if we analyse Galatians 2-6 as suggested above, but, as in the analysis proposed by Betz, it is still in a prominent position. Betz, who felt called upon to explain why such an obscure passage should be given last place, and thus greatest emphasis, in his scheme of six arguments, noted an observation in Demetrius, $\pi \varepsilon \rho i$ $\dot{\varepsilon} \rho \mu \varepsilon v i^{\prime} \alpha \varsigma^{43}$ to the effect that direct arguments are not always the most effective:

Any darkly hinting expression is more terror-striking and its import is variously conjectured by different hearers. On the other hand, things that are clear and plain are apt to be despised, just like men when stripped of their garments. Hence the Mysteries are revealed in an allegorical form in order to inspire such shuddering and awe as are associated with darkness and night. Allegory also is not unlike darkness and night.

It would certainly not be justifiable on the strength of Galatians alone to infer that Paul was acquainted with such theory. Yet notice that both in Romans 11:25 and 1 Corinthians 15:51 he actually refers to his culminating tour de force in a series of arguments as a $\mu v \sigma \tau$ njprov. Presumably for Paul this word did not have the exclusively pagan associations it conveys to the modern, classically-educated reader: $\mu v \sigma \tau$ inprov occurs in the Septuagint version of Daniel and in several books of the Old Testament Apocrypha. Even so, his use of the word with reference to his own preaching is remarkable, and, disinclined though the cautious scholar may be to allow the high seriousness of Paul's grandest preaching to be undercut in any way, one cannot totally dismiss the possibility that he had once encountered theory along the lines of Demetrius' comments on allegory.

Close study of the closing section-shall we call it the

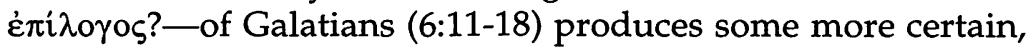

${ }^{43}$ Galatians, 239f., citing Ps.-Demetrius, De Elocutione 2.99-101. 
and equally unexpected, vindication of Betz's approach to the Epistle. ${ }^{44}$ Aristotle in the Rhetoric identifies the functions of the epilogue as follows: 'to dispose the hearer favourably towards oneself and unfavourably towards the adversary; to amplify and depreciate, to excite the emotions of the hearer, to recapitulate.' 45 As other critics have noticed, Paul does all these things in his brief postscript. But of the emotions which Aristotle lists as appropriate to rouse in one's epilogue: pity, indignation, anger, hate, jealousy, emulation and quarrelsomeness, 46 all but the first, pity ( $\varepsilon \lambda \varepsilon \circ \varsigma)$, are firmly set aside in Paul's notably eirenic conclusion. His decision on the

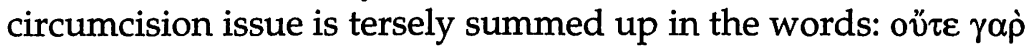

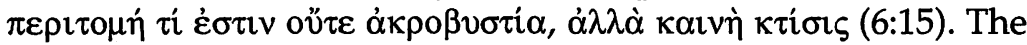

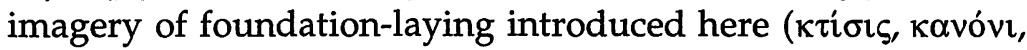

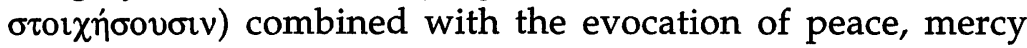
and finally the grace of the Lord Jesus Christ, are a brilliant bid for a conclusive, but forward-looking, settlement of an extremely vexatious controversy.

Paul refuses to boast, except in the cross of Christ, and here we may consider him as consciously stepping aside from a rhetorical norm. He makes no direct appeal even for pity: his

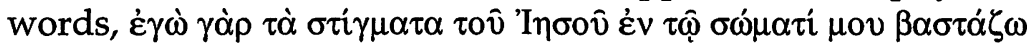
(6:17), are rather a proclamation of his apostolic authority. It nevertheless seems valid to detect here, as Betz has done, 47 a derivative from the practice, attested in Greek and Roman sources, of displaying a defendant's wounds and scars to judge or jury, in a bid both for pity and for true appreciation of the man's worth. ${ }^{48}$ It is interesting to note that an example of this oratorical ploy featured in pre-Pauline Jewish history. Josephus records how the father of Herod, Antipater the Idumaean, when defendant in a trial before Julius Caesar, 'stripped off his clothes and exposed his numerous scars. His loyalty to Caesar needed, he said, no words from him; his body cried it aloud,

${ }^{44}$ For references to ancient theory on perorations see Betz, Galatians, 313, n.8.

${ }^{45}$ Aristotle, Rhetoric 3.19 .1 (1419b, 10ff.)

46Ibid., 3.19.3 (1419b, 24ff.)

${ }^{47}$ Galatians, 323.

${ }^{48}$ See. Cicero, De Oratore 2. 28.124; Quintilian 6.1.21 cf. 30. 
were he to hold his peace.' 49 Antipater won his case, and was furthermore appointed procurator of all Judaea and authorised to rebuild ( $\dot{\alpha} v \alpha \kappa \tau i \sigma \alpha \mathrm{l}$, cognate with $\kappa \tau i \sigma i \varsigma)$ the ruined city-walls of his country. Paul, on the strength of his $\sigma \tau i \gamma \mu \alpha \tau \alpha$, saw himself as vested in comparable authority, only at an even higher level. But there is no vainglory here: $\sigma \tau i \gamma \mu \alpha \tau \alpha$ were not simply wounds but brands, a sign of the servitude of this

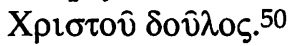

\section{Delivery, Style and Vocabulary: Paul and 'Asian' Rhetoric}

To strip a distinguished defendant of his tunic in the course of one's peroration, and reveal his scars to the jury, was reckoned by Cicero an audacious expedient, requiring great prestige, forcefulness, courage and dignity on the part of the orator. ${ }^{51}$ It was not a tactic universally approved. The inclusion of emotional appeals of any kind was frowned upon, according to Quintilian (6.1.7), by most Attic theorists and almost all philosophers who touched on the subject of rhetoric. There actually appears to have been a law against the use of such appeals at the Athenian court of the Areopagus. 52 But Paul was no Athenian. In terms of the literary criticism of his day he would surely have been regarded as an Asianus, and not only for his disinclination to eliminate non-Attic elements from his diction.53 Take Paul's avowedly insane effusions in 2 Corinthians 11:21-23:

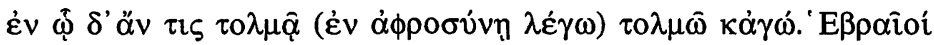



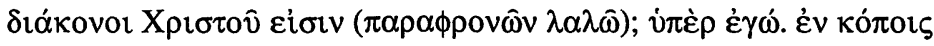
$\pi \varepsilon \rho \imath \sigma \sigma o \tau \varepsilon \dot{\varepsilon} \rho \varsigma, \dot{\varepsilon} v$ $\phi v \lambda \alpha \kappa \alpha \hat{\imath} \varsigma \quad \pi \varepsilon \rho \imath \sigma \sigma o \tau \varepsilon \dot{\varepsilon} \rho \omega \varsigma, \dot{\varepsilon} v \quad \pi \lambda \eta \gamma \alpha \hat{\imath} \varsigma$

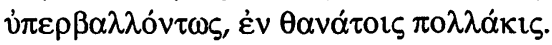

\footnotetext{
49Josephus, De bello Iudaico 1.197

50 For the association of branding with servitude see the classical references in J.J. Wettstein (Wetstenius) Novum Testamentum Graecum (Amsterdam, 1752) ad loc.

${ }^{51}$ De Oratore 2.28.124.

52Aristotle, Rhetoric 1.1.5 (1354a); cf. Athenaeus 13. 590e; Quintilian 6.1.7. ${ }^{53} \mathrm{Cf}$. Hengel, The Pre-Christian Paul, 37, who cites the discussion in E. Norden, Die antike Kunstprosa (Leipzig: Teubner, 1898) Vol. II, 492-510, which remains the most valuable introduction to Paul's writing in the context of the history of Greek prose style.
} 
The elder Seneca, that connoisseur of early Imperial rhetoric, supposing he had lived a little later and chanced to read these words, would undoubtedly have commented: Paulus ex Asianis insanissime. . .54 The Asiani, in his view, were much given to insania, which was a term of literary criticism regularly applied to cases of corrupta eloquentia. Old Seneca's literal-mindedness would have been particularly offended by the last member of the concluding tetracolon-given that one only dies once. ${ }^{55}$ Paul certainly distances himself from his 'insania' by proclaiming it ironically, but ancient grammarians have provided us with a term with which to categorise even this literary strategy, namely oxymoron, 'wise foolishness'.56

Are we to dismiss, then, as mere rhetoric the passages in which Paul distinguishes the 'wisdom of this world' ( $\tau \dot{\eta} v$

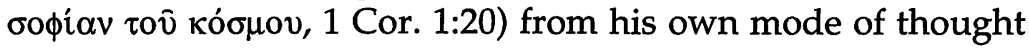
and discourse? I take the phrase quoted to refer to the array of philosophical and rhetorical presuppositions which Jews and Greeks alike had come to regard as normal under the influence of the typical Hellenistic sophist, a figure unkindly disparaged by Philo as 'an empty conglomeration of incompatible and discordant notions'.57 Superficially, as we have seen, Paul's writing shows a certain amount of indebtedness to the sophistic manner. But that does not prevent there being some clear differences from it at a more fundamental level.

It has been emerging that Paul's writing did not differ from the rhetoric 'of this world' in his manner of dispositio: it seems perfectly valid to analyse Galatians-admittedly an exceptionally terse and formal epistle by the standards of the Pauline corpus-as consisting of proem, narrative, arguments and conclusion. Nor did the difference lie in any lack of virtuosity, on Paul's part, with regard to the deployment of

54See Fairweather, Seneca the Elder, 214-223.

${ }^{55} \mathrm{Cf}$. esp. Seneca, Controversiae 9.2 .27 on a tetracolon with a redundant final member.

56See Thesaurus Linguae Latinae Vol. IX.2 (Leipzig: Teubner, 1981) s.v. oxymorus.

57Philo, Quod deterius potiori insidiari solet 72. On 'the general philosophy of the Hellenistic world' see also W.L. Knox, St. Paul and the Church of the Gentiles (Cambridge: CUP, 1939). 
rhetorical figures: it emerges from Chrysostom's commentary and from his own revealing use of $\mu \varepsilon \tau \alpha \sigma \chi \eta \mu \alpha \tau i \zeta \varepsilon \imath v$ that he was


$\sigma \chi \eta \dot{\eta} \mu \alpha \alpha \lambda \dot{\varepsilon} \xi \varepsilon \omega \varsigma$, one need only hear his epistles skilfully read aloud to acknowledge his mastery here. Yet, according to criticisms circulating in Corinth, Paul, though impressive as a





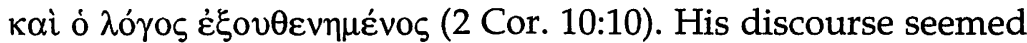
to the Corinthians somehow unprofessional: he appeared

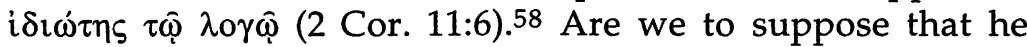
cultivated a deliberate negligence in his delivery or diction or both, which was intended to highlight qualities more important in a true believer?

We are in no position to assess just what was amiss with Paul's physical appearance and powers of delivery. Perhaps not much. Adverse criticisms of deficiencies of physical presence and delivery are commonplace in ancient character-sketches of famous literary figures: Pindar and Sophocles, Plato and Aristotle, Isocrates and Demosthenes, were all said by one critic or another to have had imperfect vocal resources. ${ }^{59}$ Paul's mission was, in spite of any deficien-

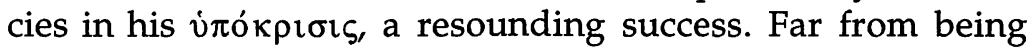
disdainful of delivery as a preaching-tool, he evidently felt that it would have helped his case if, instead of having to write a letter, he could have addressed the Galatians personally and conveyed his emotions by appropriate nuances of the voice (Gal. 4:20). His attitude to the art of delivery appears thus no different from that of a classical orator. Furthermore, Professor D.A. Russell points out to me 60 that Paul's epistolary style is

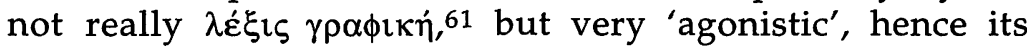

${ }^{58}$ For the converse-orations effective when delivered but $i \delta i \omega \tau \imath \kappa o i$ when written down-see Aristotle, Rhetoric 3.12.2 (1413b 18).

${ }^{59}$ See A. Westermann, Biographi Graeci Minores (1845, repr. Amsterdam: Hakkert, 1964) 95.55ff.; (Pindar); 127.23ff. (Sophocles); Diogenes Laertius 3.5 (Plato); Westermann BGM 402.2 (Aristotle); 245.14 (Isocrates); $295.62 \mathrm{ff}$. (Demosthenes).

60Per litt. 17.2.94.

61For the distinction between $\lambda \dot{\varepsilon} \xi \iota \varsigma \quad \gamma \rho \alpha \phi \imath \kappa \dot{~ a n d ~} \lambda \varepsilon \dot{\xi} \xi \varsigma \dot{\alpha} \gamma \omega v \iota \sigma \tau \iota \kappa \dot{~ s e e ~}$ Aristotle, Rhetoric 3.12.1f. (1413b 3ff.) 
obscurities. 'It is particularly striking that in letters Paul depends so much on figures that demand írókpı see him as setting standards alien to Greek sophistic by his declaration in 1 Corinthians 2:3 that he came before the

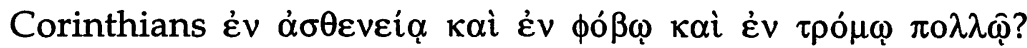
Maybe. Humility was uncharacteristic of ancient orators. On the other hand, one must not underestimate their emotionalism. A study of the use of lacrimae in Cicero's speeches would provide a good gauge of this.

What is one to say about his vocabulary and syntax? The Corinthians were not the only ancient critics to find fault with these elements of his discourse. I am told that there are numerous adverse criticisms of Paul's Greek in the Church Fathers, particularly for his non-Attic expressions, his hyperbata and his anakoloutha. 62 The modern classical scholar, judging Paul with Plato and the Attic orators in mind, has no difficulty in finding justifications for their unfavourable verdict in so far as it concerned his diction. 'Why did Paul write such bad Greek?' This is a question which has been put to me by our Professor of Classical Philology. Was it the case, perhaps, as he suggested, that Paul anticipated St. Benedict in deliberately eschewing elegance in his word-choice in the interests of a spiritual ideal? It is a difficult question to answer. Even Eduard Norden, after his wide-ranging and profound study of the history of Greek and Latin prose style, admitted to finding Pauline Greek hard to understand. 63 Since Norden's time, turnof-the-millennium Greek prose, though a Cinderella study among classicists, has been the subject of intensive research among Biblical scholars.64 The vocabulary of nearcontemporary Greek technical treatises, inscriptions and papyri is now regularly taken into account in New Testament

62Philip Kern's dissertation on Galatians (Ph.D., Sheffield, 1994) is to include a survey of such criticisms.

${ }^{63}$ Norden, Antike Kunstprosa, Vol. 2, $492 \mathrm{ff}$.

${ }^{64}$ Key works include: A. Deissmann, Licht vom Osten (1st ed. 1909; 4th ed. 1922) trans. L.R.M. Strachan, Light from the Ancient East (1927; repr. Baker: Grand Rapids, 1965); L. Rydbeck, Fachprosa, vermeintliche Volksprache und Neues Testament (Acta Universit. Upsal., Studia Graeca Upsal. 5; Uppsala: 1967); A.J. Malherbe, Social Aspects of Early Christianity (2nd. ed.; Philadelphia: Fortress, 1983). 
scholarship, along with the literary conventions of such texts. Paul's diction nonetheless continues to present a sociolinguistic puzzle.

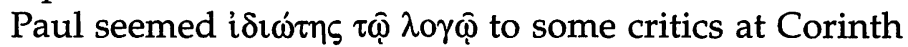
(2 Cor. 11:6; $c f .10: 10$ ), yet he clearly was not scantily educated or ungifted. His diction was of the koine and not at all classicising, yet, far from invariably adopting an informal, quasi-conversational approach to letter-writing, he emerges as a master of rhetorical figuration and his discourse frequently attains great sublimity. Indeed, he fulfils Cicero's requirement ${ }^{65}$ that for oratorical pre-eminence one should be able to range through all the registers of style. We may fairly say of Paul, as the purist Messalla Corvinus remarked of a Latin rhetorician from Spain, that he was 'eloquent in his own language'.66 Why, then, did he keep to the koine, unrefined? We may conjecture that in his formative years, Atticism had yet to make any great impact in the parts of the Roman world where he was living. On the other hand, there were undoubtedly traditions of highflown rhetoric in the cities of Asia Minor. Though developed against the Aramaic-speaking background of the former Persian Empire, and subject to the pressures which cause all languages to change over the centuries, 'Asian' rhetoric nonetheless represented a continuation of a sophistic in which Athens and the Attic dialect had been prominent; it retained most of that dialect's vocabulary while expanding on it, and it certainly aspired to a splendour and elevation far removed from the conversation of ordinary people.67 The influence of Asiatic magniloquence extended even to Latin orators, Cicero not excluded. 68

I have noted certain affinities which Paul's epistolary manner bears to the 'Asian' tendency in rhetoric. However, neither his general approach nor his diction reminds one at all either of Hegesias of Magnesia or Antiochus I of Commagene,

${ }^{65}$ E.g. Orator $5.20-22 ; 20.56 ; 21.69 f$.

66Seneca, Controversiae, 2.4.8.

67See e.g. Cicero, Brutus 8.25; 13.51; 95.325f.; Quintilian 12.10.16f.

${ }^{68}$ Cicero admits in Brutus 92.317 to having been in his youth keen to imitate Hortensius, whose style is likened (ibid., 95.325) to that of Asiatic Greek orators. See also Quintilian 12.10.12. 
the remains of whose prose are discussed by Norden as chance survivors of that tendency, ${ }^{69}$ so a problem remains. Paul's use of the koine as the vehicle for his preaching may perhaps seem easiest accounted for if, in line with Hengel, we assume that in his youth he had shunned the pagan intellectual ferment of Tarsus and had confined his reading strictly, at least in his preconversion days, to Jewish literature, that he had never actually read Menander, Epimenides or Aratus in extenso, that he only knew of pagan philosophy at second hand, and that his knowledge of rhetorical theory had been derived exclusively from a training for synagogue-preaching. However, the hypothesis of Jewish isolation will not explain everything: the

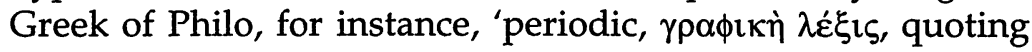
the Bible a good deal but not letting its oddity influence the general texture of his style', ${ }^{70}$ will serve as a reminder of the diversity of styles to be found within Jewish-Greek literature.

As an alternative, we may hypothesise that Atticism had made no impact on the Greek of Asia Minor and Palestine as early as Paul's youth; that the koine, in some shape or form, would have been the language used by the pagan sophists of Tarsus as well as the synagogue-preachers of Greek-speaking Jerusalem. In that case, it would simply have seemed the only option open to him, so far as diction was concerned. ${ }^{71}$ It may be suggested that Atticism perhaps reached Corinth, a short journey from Athens, before the more easterly cities along Paul's missionary route, hence the poor view taken there of his preaching style. However, there are difficulties in the way of supposing that all Asian discourse was equally modernist, unrefined and removed from Attic norms.

If neither position so far suggested is found entirely acceptable, three further partial explanations for Paul's diction could be mooted: that he adopted the koine for grammatical, political, or reverential reasons. There existed in his time a grammatical school of thought, the anomalists, who differed from their rivals, the analogists, in taking the Greek language,

${ }^{69}$ Norden Antike Kunstprosa, Vol. 1, $134 \mathrm{ff}$.

70D.A. Russell, per litt. 17.2.94.

${ }^{71}$ See Philostratus, Vitae Sophistarum 578, for an anecdote in which a much later Cilician sophist drops a linguistic clanger. 
with all its abnormalities, as they found it. To cite J.F. Mountford's entry on these two schools in the Oxford Classical Dictionary:

Underlying the controversy was the question (already discussed in Plato's Cratylus; cf. Lucr. 5.1028-90) whether language was a natural growth or an arbitrary convention; and though matters of style did not at first enter into the argument, the analogists tended to be allied with purists in their condemnation of barbarisms and solecisms, and anomalists with those who claimed a place for new coinages and modes of expression.

It is quite conceivable that Paul, as a learned man, was aware of this controversy, in which Alexandrian grammarians figured prominently, and with the anomalists' theoretical justification for keeping to the koine. We may also note that adopting a demotic in preference to a katharevousa, to use the modern Greek terms, is something which people have been known to do for political reasons. Did the circle of Gamaliel perhaps keep to the Greek of the common people in order to distinguish themselves from the hated Roman authorities? Was Paul's use of it in Christian preaching a populist choice? Another motive for distinctive dialectal choice in Greek is reverence for earlier exemplars of a literary tradition. One factor which could have retarded abandonment of the koine in Jewish circles would have been its enshrined status in the Greek Old Testament. Did Paul also feel obliged, for generic reasons, to adopt the same type of Greek as the 'pillars of the Church'? Spiritual considerations, the Apostle's awareness for the need for humility, for instance, are certainly to be given due weight, together with the general antipathy towards the thought-world of the pagan sophists which he shared with Philo. That said, I find it hard to believe that the word-choice and syntactical practices adopted by Paul were other than those which came most naturally to him.

More than any other text, I have found 4 Maccabees helpful for suggesting possible reasons why some of Paul's hearers might have found his preaching manner disappointing. Here is a patriotic Jewish author expounding a $\theta \dot{\varepsilon} \sigma \iota \varsigma$ with amazing copiousness and fluency. The freely imaginative 
depiction of the martyrdoms which figure prominently in his book suggest a mind little troubled by considerations of absolute truthfulness. No opportunity for rhetorical amplification is left unexploited; no gruesome twist is spared.72 The whole is decidedly flashy, and permeated by a certain Stoic-influenced heartlessness. Was this maybe something like the mode of preaching to which synagogue-goers in Corinth had been accustomed before Paul's mission? Paradoxically, the diction and style of the hard-line Jewish nationalist author represent a resounding triumph for the mainstream Greek rhetorical tradition over the Hebrew-permeated koine in which the earlier books of the Septuagint are couched.

Whether or not one regards Paul's use of the koine as a radical or deliberate departure from the sophistic standards of his time and place, there is one obvious respect in which his vocabulary is alien to that of the pagan philosophers. The Old Testament in translation must have been the primary influence on Paul's literary style. The linguistic habits of the Christian communities he encountered in the early days after his conversion would have been formative too. To the extent that the abstract terms deployed in orthodox Jewish circles and in early Christian congregations, under Biblical influence, were new coinages or implied something different from the same words as used by pagan Greek philosophers and by Jews who had succumbed to their influence, Paul's diction sets him apart from the ooфi $\alpha$ of this world.

\section{Christ-based logic: a new foundation}

Further divergences from pagan sophistic, and surely the most important ones, are to be found in the presuppositions underlying Paul's mode of argumentation. We have noted that he does not conduct ethical discussions along the clichéd lines recommended in the Rhetorica ad Alexandrum and the progymnasmatic treatises. His approach to questions of fact was also decidedly not that of the Greek rhetorical tradition.

72N.b., however, Paul refers in Gal. 3:1 to graphic representation of the crucifixion during his Galatian mission: we must be careful not to assume that the gruesomeness of 4 Maccabees sets it in complete contrast to the Pauline manner. 
One thing that sets Paul firmly apart from this tradition is his assumption of an other-worldly authority on the basis of what he calls $\pi$ iotıs. Though the authority he claims cannot be regarded as totally distinct from the auctoritas which was the boast of many an ancient orator, his $\pi i \sigma \tau \imath \varsigma$ - 'faith', for want of a better translation-was certainly something utterly different from the $\pi$ i $\sigma \tau \varepsilon \iota \varsigma$ 'persuasives, proofs, rhetorical arguments', deployed by the intellectual heirs of the 5th-century sophists. To Gorgias of Leontini, according to Plato, $\pi i \sigma \tau \varepsilon \imath \varsigma$, were matters of opinion, not certainty, and were to be presented merely with as much verisimilitude as possible, since the search for absolute truth was not practicable in the limited time available to orators in courts of law and assemblies. ${ }^{73}$ To Paul, $\pi i \sigma \tau \varsigma$ was an absolute reality, deducible from his conversionexperience. One has to have experienced something comparable in order to understand its power over a person's whole thinking. Paul's $\pi i \sigma \tau \iota \varsigma$ was stronger even than that kind of faith in the religion of one's forebears railed against uncomprehendingly by Richard Dawkins in his recent journalism:

If you ask people why they are convinced of the truth of their religion, they don't appeal to heredity... they appeal to faith. Faith is the great cop-out, the great excuse to evade the need to think and evaluate evidence. Faith is belief in spite of, perhaps because of, lack of evidence. The worst thing is that the rest of us are supposed to respect it, to treat it with kid gloves. ${ }^{74}$

Paul believed that he had received 'evidence' enough on the road to Damascus, evidence which certainly could not be explained in terms of heredity. His conviction was thus, as he

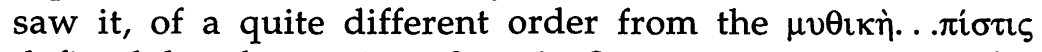
defined by the ancient Sceptic Sextus Empiricus as the acceptance' ( $\left.\pi \alpha \rho \alpha \delta \circ \chi \eta^{\prime}\right)$ of non-existent and fictitious things,

73Plato, Gorgias 455a.

${ }^{74} \mathrm{R}$. Dawkins, 'The Scientist's case against God', Independent 20.4.1992, p. 17. 
such as the myths about Cronos' (Pyrrhoneioi Hypotyposeis 1.147). ${ }^{75}$

But how to convey this conviction to others? The hearing of an other-worldly voice would have been reckoned in Paul's time, as now, an unusual type of evidence on which to base any sort of argumentation. Near the end of Quintilian's treatment of 'inartificial proofs' (5.1.1ff.), there is indeed mention of supernatural testimonies-oracular responses, prophecies and omens-but the dismissive formula with which they are introduced (5.1.35) suggests that they would in fact rarely have been encountered in contemporary Roman lawcourts. Sextus Empiricus, in his relativistic account of senseperception, sums up concisely the problem confronting Paul: oi

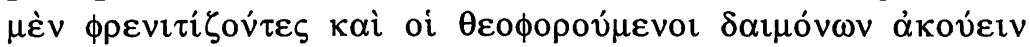

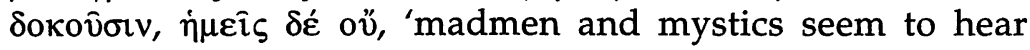
divinities, while we do not' ( $P H$ 1.101). Paul's first reply to any who cast doubt on the validity of his $\pi i \sigma \tau \iota \zeta$ was to recount the story of his conversion: he does this in Galatians, and, to judge from Acts, he did the same on many other occasions. To any in his congregations who, like the Sceptics, asserted that proof cannot be revealed by a sign because the sign itself requires proof (Sextus Empiricus, $P H$ 2.182), he could appeal to the evidence of their own individual and collective past experience

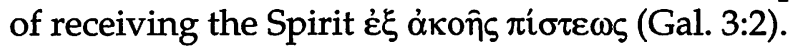

It is a proud Christian boast, with Pauline precedent ( 1 Cor. 3:11), that 'Christ is our cornerstone.' Cicero might claim that the foundation of eloquence was wisdom (Orator 21.70) but, in practice, the flimsy and flexible cornerstone of most Greek sophistic reasoning, where it concerned questions of fact, was something of much less solid worth, namely the concept of Eikós, 'probability', 'verisimilitude'.76 In exploring 'likelihoods' where no positive proof exists, modern academic research, this paper not excepted, follows the example of the sophists. The importance of the concept of probability in both Greek and Roman philosophy and rhetoric is readily demonstrated. A Thesaurus Linguae Graecae word-search discovered a startling

75Text and translation in Sextus Empiricus, ed. and trans. R.G. Bury (Cambridge, Mass./London: Heinemann, 1933) Vol. 1.

76See Aristotle, Rhetoric 2.24.10ff. (1402a 14ff.) 



Aristotelian corpus, over 200 in Demosthenes and comparably high numbers in other Attic orators. ${ }^{77}$ In Cicero we find over 100 usages of probabilis and about 90 of veri similis/verisimilis. But look in a concordance of the canonical books of the Bible for the word 'probable' and you will not find it. Eikós occurs nowhere in the New Testament and in the whole Septuagint only once, in 4 Maccabees 9:2, the context being a highly declamatory concerted speech put into the mouths of seven Jewish martyrs. That Paul, in common with the other New Testament writers, completely avoided a concept which Greek philosophers and orators found so useful, can hardly be the result of his never having encountered it. It is not as if all Jewish writers of his time saw a need for abstention from it: in Philo, عi có $\varsigma$ features over 360 times. No. Paul's avoidance of the term is surely an important feature of his rejection of the $\pi \mathrm{i} \theta \alpha v 0 \lambda$ ori $\alpha$ (Col. 2:4) of the sophists and his radical desire to

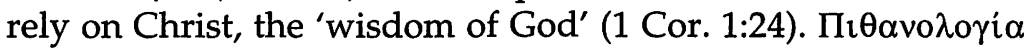
and हiкó $\tau \alpha$ ('probabilities') are represented as closely associated by Socrates (recalling the views of Protagoras) in Plato's Theaetetus (163e). Philo, in De praemiis et poenis 28-30, anticipates Paul in presenting $\pi i \sigma \tau \varsigma$, the outcome of revelation, as superior to reasoning, sense-perception, and opinion based on

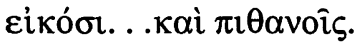

On the basis of his $\pi$ írı and his consequent sense of apostolic authority, Paul adopted a stance, in relation to the congregations to which he writes, which is notably paternal-

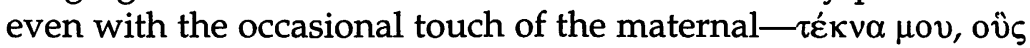

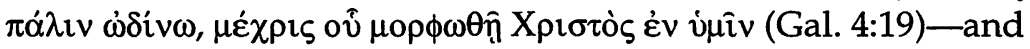
seems to owe not a little to the model of 'God in the Old Testament'. But Paul was no ordinary exponent of what has been termed 'sacred language'. ${ }^{78} \mathrm{He}$ stands in as sharp contrast to the Sicilian Greek healer and preacher, Empedocles, who in one of his poems announced to the people of Acragas, 'I go

\footnotetext{
77These figures exclude dative plural usages, owing to the need to exclude Eikool ('twenty') and its compounds from the search.

78See E. Grassi, Rhetoric as Philosophy: the Humanist Tradition (University Park and London: Pennsylvania State University Press, 1980) cited by G. Kennedy, New Testament Interpretation and Rhetorical Criticism, 6.
} 
amongst you an immortal god, no more a mortal',79 as he does to Protagoras, who excluded mention of gods from his discourse, as being mere probabilities (Plato, Theaetetus, loc. cit.) He may be contrasted also with the Old Testament prophets: he did not claim invariably to be delivering 'the word of the Lord'. He had not lost sight of his human fallibility and it is interesting to see him struggling, on occasion, to be perfectly honest about the limitations of his authority, and not to reject the demands of his reasoning intellect. In 1 Corinthians 7 we have seen him drawing a sharp distinction between an occasion when it is 'not himself but the Lord' who is speaking (v. 10) and another where he has 'no command from the Lord' and can only offer an opinion (v. 25). Later in the same Epistle (14:18f.) he writes: 'I thank God that I speak tongues more than you all; nevertheless in church I would rather speak five words with my mind in order to instruct others, than ten thousand words in a tongue.' Paul's speaking in tongues would seem to put him a million miles, intellectually, from the world of Cicero and Seneca, and yet there was something checking him from total abandonment of the kind of human rationality which they represented. In part this must have been the rigour of his past intellectual training, but we should remember too that Paul lists 'self-control' amongst the fruit of the Spirit (Gal. 5:22).

To the question whether it is appropriate to analyse the Epistle to the Galatians in terms of classical rhetoric, I have felt obliged by the evidence to give the answer 'Yes-up to a point.' We have chiefly been looking at its affinities in the areas of layout and figuration. The slanted vehemence of the Epistle also calls for comparison with the Greek tradition of making the weaker case seem the stronger. In Galatians, Paul was presenting himself 'to those outside the law, as one outside the law', while being aware that on other occasions he would have to become 'as a Jew, in order to win Jews' (1 Cor. 9:19ff.). It is startling how angrily he replies to what may have been quite a harmless-sounding enquiry from the Galatians: 'Some missionaries have come saying that in order to conform fully to

${ }^{79}$ Empedocles Katharmoi, line 4 ap. Diogenes Laertius $8.61=$ fr. 102 (112), in Empedocles: the Extant Fragments, ed. M.R. Wright (New Haven/London: Yale UP, 1981). 
God's law the non-Jews amongst us ought to be circumcised. They say that this is the practice advocated by "the pillars of the Church" and that you have only been preaching otherwise in order to indulge us. Please would you clarify your position on this matter.' Between the forcefulness of Paul's epistolary manner in Galatians and the ambling discursiveness of the sermons of Teles, the 3 rd-century B.C. Cynic preacher, ${ }^{80}$ there is a difference in intensity comparable to that between Juvenal's Satires and the early Sermones of Horace. In the latter case, the difference is generally accepted to be chiefly attributable to Juvenal's training in the Roman schools of declamation: in Paul's, we can only speculate as to whether synagogue-training alone, combined with a fiery temperament and deep convictions, would have been sufficient to account for the uncompromising one-sidedness of his response to the Galatians.

It does not follow from this cautiously affirmative answer to the question about Paul's indebtedness to the tradition of classical rhetoric that we are obliged to believe, with Betz, 81 that Paul's addressees in Galatia were from an educated élite. It should be remembered that the most sophisticated orators, preachers and letter-writers sometimes find themselves addressing unsophisticated people, and do not necessarily adjust their mode of discourse to an entirely appropriate level. Furthermore, the main point of rhetorical sophistication is that it gives the speaker a psychological advantage over audiences lacking his training. Classical rhetorical theory was first systematised in the democracies of Sicily, and it was observed, in the early Roman Empire, that rhetoric had flourished pre-eminently where orators had turbulent mass assemblies to address.82 It would seem justifiable to surmise that Paul's Corinthian addressees included people with a high level of education, given their sophisticated criticisms of Paul's preaching, and his assumption

\footnotetext{
${ }^{80}$ Teles ed. and trans. E. O’Neil (Missoula: Scholars Press, 1977).

${ }^{81}$ Betz, Galatians, 2.

${ }^{82}$ See Tacitus, Dialogus $36.1 \mathrm{ff}$. where an account of conditions under the late Roman Republic had evidently once been preceded by a discussion, now lost, of the earlier development of rhetoric in the Greek world.
} 
that they will understand the term $\mu \varepsilon \tau \alpha \sigma \chi \eta \mu \alpha \tau i \zeta \varepsilon \imath v$, but it would be unwarranted to argue similarly on the basis of Paul's not obviously technical use of $\mu \alpha \kappa \alpha \rho \imath \sigma \mu o ́ s$ in Galatians. Some familiarity, on the part of his addressees in Galatia, with the allegorical approach to Scripture seems to be presupposed by Paul, but not a particular expertise in rhetoric.

It does not necessarily follow either, from acceptance that Paul owed something to the Greek art of persuasion, that he had actually attended a school of rhetoric or that he had been brought up on an extensive reading of the pagan classics. It remains possible to defend the hypothesis that his studies, even after his conversion, could have been strictly confined to the realm of Jewish literature, this being, by the 1st century A.D., rich, variegated and long subject to sufficient influences from the pagan Greek world to account for the level of indebtedness to Hellenism displayed by Paul. Not that it would be wise to promote this theory too rigidly or to dismiss any quest for seeming classical allusions in the Epistles as pointless: the post-conversion Paul, travelling the open road with his heart set upon finding points of spiritual contact with the Gentiles, was a very different person from the strictly broughtup youth who had studied the Torah in Jerusalem. Acts 18:23 reports an occasion when he found a starting-point for a sermon in a pagan religious inscription. He would have seen plenty of those on his travels, along with the inscribed propaganda of political leaders, past and present. Also, given the way that Greek philosophy was customarily expounded and debated outdoors and orally, it is inconceivable that on his journeys through the Eastern Roman Empire he could have escaped learning a great deal about Stoicism, Epicureanism and the other schools of pagan thought, if not through the written word, then informally, from fellow-travellers, from lecturers holding forth in market-places and beneath the porticoes of public buildings, from tavern bores. It is uncertain how much experience Paul would have had, before writing Galatians, of Roman judicial practice, but I doubt if it was negligible.

However great we may consider Paul's debt to have been to Hellenistic rhetoric, it need not follow that he would have had an easy conscience with regard to mendacity: his 
ideal of persuasion 'in the knowledge of the fear of the Lord' should not be lightly dismissed as a pretence, even granted that, being human and involved in an immensely difficult task, he was bound sometimes to fall short of his aspirations. Nor do his invectives against the $\sigma o \phi i \alpha$ of this world have to be dismissed as hypocrisy. By his rejection of standard Hellenistic modes of argumentation and his reliance, instead, on an

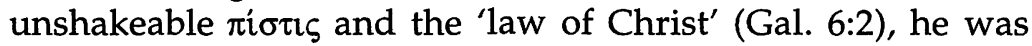
indeed departing from contemporary pagan and Hellenized Jewish practice, and, in literary as well as in spiritual terms, was laying down a new foundation. 